\title{
Immunoprecipitation of Triton X-100-solubilized Mycoplasma mycoides Proteins
}

\author{
By D. B. ARCHER* \\ CSIRO, Animal Health Research Laboratory, Private Bag No. 1, \\ P.O., Parkville, Victoria 3052, Australia
}

(Received 25 January 1979)

\begin{abstract}
Mycoplasma mycoides subsp. mycoides (PG1 and strain $\mathrm{Y}$ ) proteins were solubilized in Triton $\mathrm{X}-100$, and the antigenic proteins were precipitated from this complex mixture by addition of antiserum and then separated by two-dimensional gel electrophoresis. Of the 300 proteins solubilized, about 10 were precipitated. Proteins of PG1, a slow-growing, small colony (SC) strain, were precipitated by antiserum to PG1 and by antiserum to strain Y, a fast-growing, large colony (LC) strain. Similarly, strain Y proteins were precipitated by antiserum to PG1 and by antiserum to strain Y. The few proteins precipitated in this way gave similar patterns after two-dimensional gel electrophoresis indicating that many of the dominant protein antigens of PG1 and strain Y are shared. Antiserum to Mycoplasma mycoides subsp. capri (PG3) also precipitated some proteins of strain $\mathrm{Y}$. Antiserum to Mycoplasma gallisepticum gave no reaction with any $M$. mycoides antigens. It was concluded that, in addition to the polysaccharide antigens, there are proteins in $M$. mycoides that are antigenic and that some of these are found in both the SC and LC strains of subsp. mycoides and also in subsp. capri.
\end{abstract}

\section{INTRODUCTION}

Mycoplasma mycoides subsp. mycoides may be conveniently subdivided into two types: a slow-growing, small colony (SC) type of which PG1 is representative, and a faster-growing, large colony (LC) type of which strain Y is typical (Cottew \& Yeats, 1978). PG1 and strain $\mathrm{Y}$ are antigenically related (Laws, 1956; Hudson et al., 1967; Al-Aubaidi et al., 1972), the major antigen being galactan (Buttery, 1970), and this distinguishes the subsp. mycoides from subsp. capri which synthesizes a glucan (Jones et al., 1965).

The electrophoretic patterns of cell proteins have been used in taxonomic studies of mycoplasmas (Razin, 1968; Rodwell \& Rodwell, 1978) and it is clear that PG1, strain Y and Mycoplasma mycoides subsp. capri (PG3) have some proteins in common but also many differences. It was therefore of interest to investigate whether proteins of $M$. mycoides subsp. mycoides elicit antibody production after injection of killed cells into rabbits and, if so, to determine which of these proteins were common to PG1 and strain Y.

The technique of high-resolution two-dimensional gel electrophoresis, with separation in the first dimension by isoelectric focusing and in the second dimension by polyacrylamide gel electrophoresis in the presence of sodium dodecyl sulphate, has been adapted in this laboratory for the separation of mycoplasma proteins (Archer et al., 1978). This technique has been employed by others to separate protein antigens precipitated from complex mixtures of proteins by antibodies (Ghangas \& Milman, 1977; Jones, 1977). In the work described here, mycoplasma proteins were solubilized by the detergent Triton X-100 and

* Present address: John Innes Institute, Colney Lane, Norwich NR4 7UH. 
then the antigenic proteins were precipitated from this mixture of proteins by antisera against a number of different mycoplasmas. The precipitated proteins were then separated by two-dimensional gel electrophoresis.

\section{METHODS}

Organisms and growth. Two Mycoplasma mycoides subsp. mycoides strains (PG1 and Y) and M. mycoides subsp. capri (PG3) were used in this work. PG1 and PG3 are the type strains of $M$. mycoides subsp. mycoides and subsp. capri, respectively. The M. mycoides subsp. mycoides strain Y2a variant (Rodwell et al., 1972) of the original strain Y isolate (Laws, 1956) was used throughout, and will be referred to as strain Y. These organisms were grown in medium containing $\left[\mathrm{U}_{-}{ }^{14} \mathrm{C}\right]$ protein hydrolysate $\left(2.5 \mu \mathrm{Ci} \mathrm{ml}{ }^{-1}\right.$; The Radiochemical Centre, Amersham) as described previously (Rodwell \& Rodwell, 1978).

Mycoplasma gallisepticum strain 89 LDAS, from G. Cottew in this laboratory, was grown in a medium containing: PPLO broth (Difco), $2 \cdot 1 \%$ (w/v); Albimi yeast autolysate (Pfizer), $0 \cdot 6 \%(\mathrm{w} / \mathrm{v}$ ); DNA (calf thymus), $0.002 \%$ (v/v); yeast extract (Herderscheê, 1963), $10 \%$ (v/v); sodium $N$-2-hydroxyethylpiperazine$N$-2-ethanesulphonate, $0.05 \mathrm{~m}$; horse serum, $20 \%(\mathrm{v} / \mathrm{v}) ;$ glucose, $0.5 \%(\mathrm{w} / \mathrm{v}) ; \mathrm{pH} 7 \cdot 8$. Cells were harvested in the late-exponential phase of growth as determined by absorbance at $650 \mathrm{~nm}$.

Solubilization in Triton $X-100$. Cells were harvested by centrifuging at $17300 \mathrm{~g}$ for $15 \mathrm{~min}$ in a Sorvall RC2-B centrifuge and washed twice in phosphate-buffered saline $(12 \mathrm{~mm}$-sodium phosphate, $0.145 \mathrm{M}$ sodium chloride, $\mathrm{pH} 7.0 ; \mathrm{PBS})$. They were resuspended in PBS containing $1 \%(\mathrm{w} / \mathrm{v})$ Triton X-100 at a final cell protein concentration of $1 \mathrm{mg} \mathrm{ml}^{-1}$ and incubated for $15 \mathrm{~min}$ at $20^{\circ} \mathrm{C}$. Insoluble material was then removed by centrifuging at $27000 \mathrm{~g}$ for $30 \mathrm{~min}$. The Triton X-100 extracts were stored at $4{ }^{\circ} \mathrm{C}$ and used within 1 week. After this period some non-specific agglutination of solubilized material occurred.

Immunoprecipitation of solubilized proteins. All antisera used in this work were very kindly donated by G. Cottew. The antisera were from rabbits injected repeatedly with suspensions of thiomersalate-killed cells (Hudson et al., 1967). Precipitation of solubilized protein antigens was tested initially on Ouchterlony doublediffusion gels [agar, $2 \%(\mathrm{w} / \mathrm{v}), 1 \mathrm{~mm}$ thick on microscope slides]. Triton X-100 extracts and antisera were placed in appropriate wells and precipitin lines were allowed to form over a period of $16 \mathrm{~h}$ at $20^{\circ} \mathrm{C}$.

The immunoprecipitation reaction for analysis by two-dimensional gel electrophoresis was performed by mixing the Triton X-100 extract (normally $0.1 \mathrm{ml}$ ) with the serum (normally $0.2 \mathrm{ml}$ ). Precipitation was evident soon after mixing, but incubation was continued for $16 \mathrm{~h}$ at $4{ }^{\circ} \mathrm{C}$ to allow complete precipitation and aggregation. The precipitate was then pelleted by centrifuging at $17300 \mathrm{~g}$ for $15 \mathrm{~min}$ and washed in PBS. In each assay an excess of serum was used, such that addition of more serum did not precipitate any more antigen. Addition of Triton X-100 $(1 \%, w / v)$ to the serum did not alter the extent of the immunoprecipitation.

Two-dimensional gel electrophoresis. The ${ }^{14} \mathrm{C}$-labelled immunoprecipitate was solubilized in a mixture of $8 \mathrm{M}$-urea, $2 \%(\mathrm{w} / \mathrm{v})$ Triton $\mathrm{X}-100,2 \%(\mathrm{v} / \mathrm{v})$ ampholines (LKB) $(1 \% \mathrm{pH}$ range 5 to $7 \mathrm{plus} 1 \% \mathrm{pH}$ range 3.5 to 10$), 12 \%(\mathrm{w} / \mathrm{v})$ sucrose, $5 \%(\mathrm{v} / \mathrm{v}) \beta$-mercaptoethanol and $0.001 \%(\mathrm{w} / \mathrm{v})$ bromophenol blue, and the proteins were separated by two-dimensional gel electrophoresis (Archer et al., 1978). The electrophoretograms were examined by fluorography (Laskey \& Mills, 1975) so that only the protein antigens were detected. Approximately $10^{4}$ d.p.m. were applied to each gel and the fluorograms were exposed for about $20 \mathrm{~d}$ at $-70^{\circ} \mathrm{C}$.

\section{RESULTS}

\section{Ouchterlony double-diffusion}

The precipitation of solubilized antigens by antisera on double-diffusion gels is shown in Fig. 1. Two distinct types of precipitation lines are evident: strong, broad lines and weaker, but sharp lines. This suggests immunoprecipitation of different types of antigen, and the Triton X-100 extracts used in this work could contain a number of possible antigens, including glycolipid, protein and polysaccharide (Buttery \& Plackett, 1960). Triton X-100 alone did not produce any precipitin lines with any of the sera used. Both types of precipitin line are produced by the interaction of either strain Y or PG1 antigens with antisera to strain $Y$ and to PG1, and by PG3 antigens with antiserum to PG3. Only weak, sharp lines are produced by the interaction of either strain Y or PGl antigens with antiserum to PG3, and by PG3 antigens with antiserum to PG1 and strain Y. As would be expected, antisera to $M$. gallisepticum strain 89 LDAS did not precipitate any $M$. mycoides antigens. 

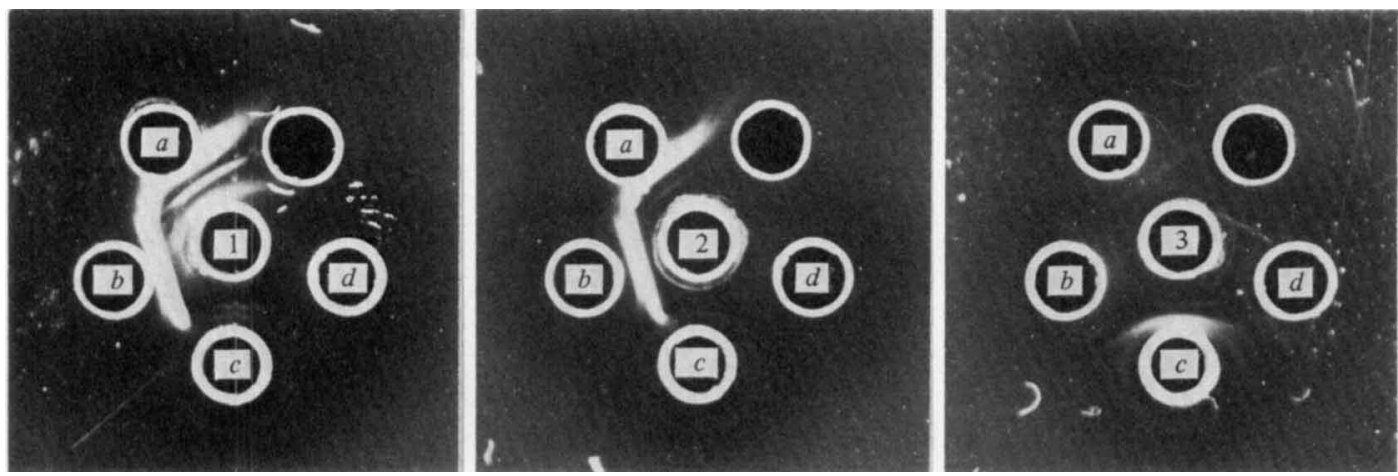

Fig. 1. Double-diffusion frecipitation. Mycoplasma antigens solubilized in Triton X-100 and antisera to mycoplasmas were placed in the indicated wells of an agar slide. Precipitin lines formed after a few hours. Antigens: 1, strain Y; 2, PG1; 3, PG3. Antisera: $a$, strain Y; $b, \mathrm{PG} 1 ; c$, PG3; d, M. gallisepticum (strain 89 LDAS).

Table 1. Immunoprecipitation of solubilized mycoplasma antigens

Antigens were precipitated from $M$. mycoides subsp. mycoides (PG1 and Y), $M$. mycoides subsp. capri (PG3) and $M$. gallisepticum (89 LDAS) cells solubilized in Triton X-100 by the addition of rabbit antiserum to these mycoplasmas.

Rabbit antiserum to:

\begin{tabular}{|c|c|c|c|c|}
\hline Antigen & $Y$ & PG1 & PG3 & 89 LDAS \\
\hline $\begin{array}{l}\text { Y } \\
\text { PG1 }\end{array}$ & $\begin{array}{c}+++ \\
+++\end{array}$ & $\begin{array}{c}++++ \\
+++\end{array}$ & $\begin{array}{c}++ \\
\pm\end{array}$ & - \\
\hline $\begin{array}{l}\text { PG3 } \\
89 \text { LDAS }\end{array}$ & + & $\stackrel{I}{-}$ & $\begin{array}{c}++++ \\
-\end{array}$ & $+\overline{+}++$ \\
\hline
\end{tabular}

- , No precipitation;,,+++++++++ , increasing precipitation; \pm , faint precipitation.

\section{Immunoprecipitation of solubilized protein antigens}

The precipitation of solubilized protein antigens by different antisera is summarized in Table 1. The extent of precipitation, which includes precipitated polysaccharide and protein antigens, was judged visually using dark-ground illumination. These results confirmed those obtained in the double-diffusion tests. Mycoplasma strain $\mathrm{Y}$ antigens were precipitated by antisera to Y, PG1 and PG3. Mycoplasma PG1 antigens were precipitated by antisera to $\mathrm{Y}$ and PG1 and there was a slight reaction with antiserum to PG3 though this did not give sufficient precipitation for analysis by two-dimensional gel electrophoresis using routine quantities of antigen and antiserum. However, PG1 and PG3 do have some similarities in protein pattern (Rodwell \& Rodwell, 1978) and some of these common proteins are probably antigenic. Mycoplasma gallisepticum was included in this series of reactions as a control. There was no reaction between $M$. mycoides and antiserum to $M$. gallisepticum.

The two-dimensional gel electrophoretic patterns of the proteins of strain Y and PG1 are shown in Figs. 2 and 3, respectively. The Triton X-100 extracts of strain Y and PG1 showed some similarities of pattern but many differences, as would be expected (Rodwell \& Rodwell, 1978). The proteins of strain Y precipitated by antisera to strain Y or PGl are shown in Figs 2(a) and 2(b), respectively, and the proteins of PG1 precipitated by antisera to strain Y or PG1 are shown in Figs $3(a)$ and $3(b)$. The protein patterns may be compared by fixing the coordinates of individual spots using the scales in the figures. In both figures, separation was by isoelectric focusing in the first (horizontal) dimension and by polyacrylamide gel electrophoresis in the second (vertical) dimension. Protein A (mol.wt 85000), a major membrane-associated protein of LC strains of subsp. mycoides (Rodwell et al., 1975), was shown to elicit antibody formation and was only precipitated from 


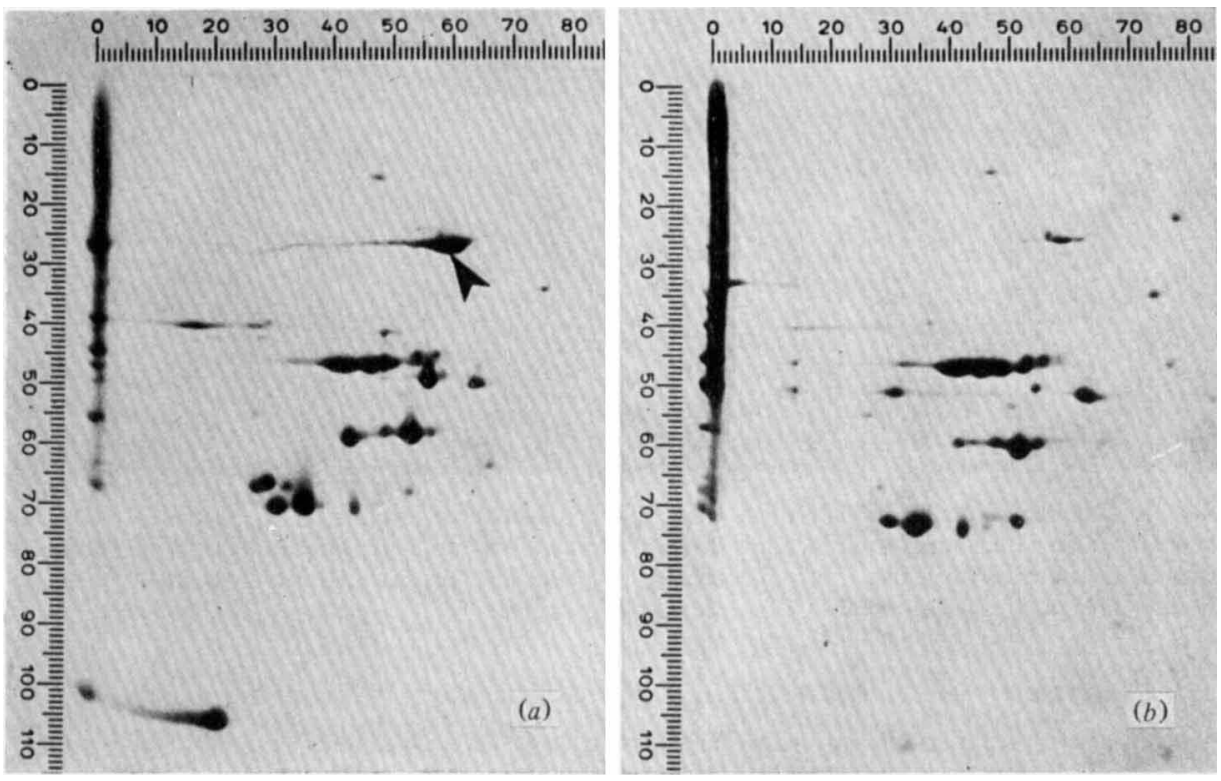

Fig. 2. Immunoprecipitation of strain $Y$ proteins. Two-dimensional gel electrophoretograms of strain Y proteins precipitated by antisera to strain Y $(a)$ and PG1 $(b)$. The arrow in $(a)$ indicates protein $\mathrm{A}$ (see text). All proteins were labelled with ${ }^{14} \mathrm{C}$ and detected by fluorography. Separation in the first (horizontal) dimension was by isoelectric focusing and in the second (vertical) dimension by polyacrylamide gel electrophoresis. The scales are in $\mathrm{mm}$.
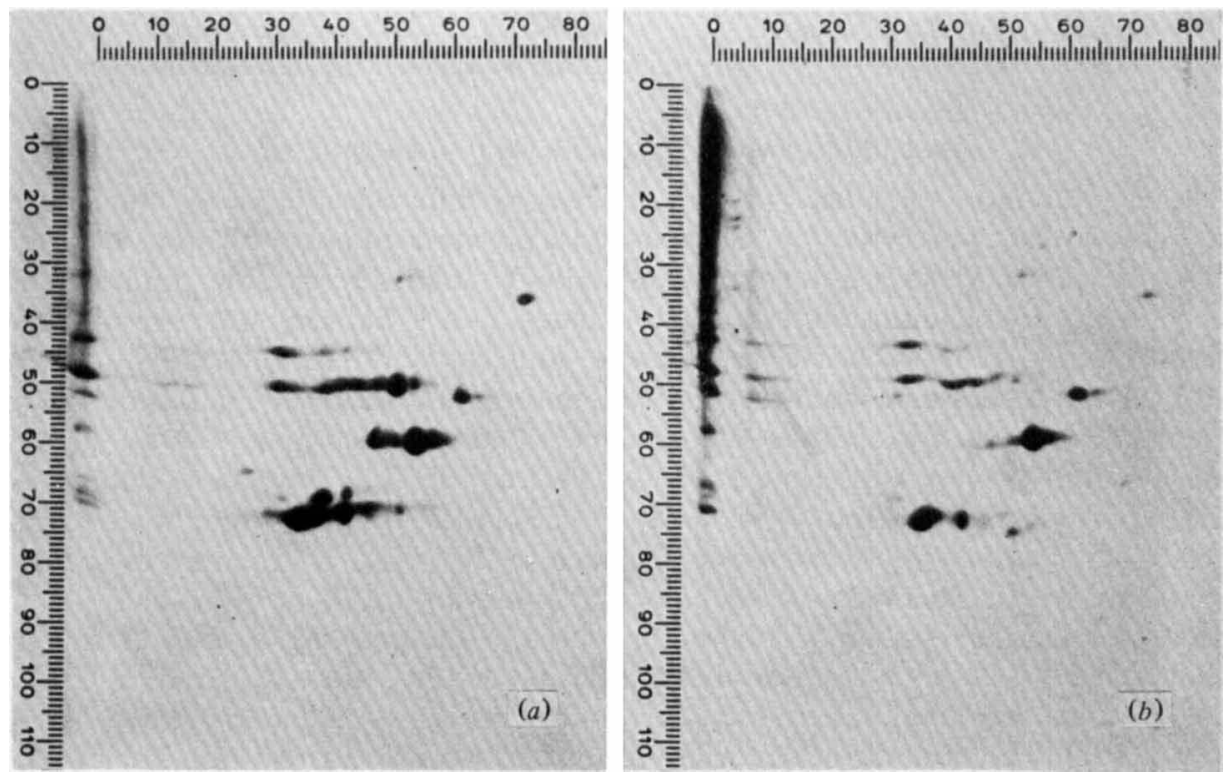

Fig. 3. Immunoprecipitation of PG1 proteins. Two-dimensional gel electrophoretograms of PG1 proteins precipitated by antisera to strain Y $(a)$ and PG1 $(b)$. Other details as in Fig. 2.

solubilized strain $\mathrm{Y}$ antigens by antiserum to strain $\mathrm{Y}$. Protein A (coordinates $58 \times 26$ ) is arrowed in Fig. 2(a), and although a very small spot does appear at the same coordinates in Fig. $2(b)$, this is probably due to incomplete removal by washing of unprecipitated proteins from the immunoprecipitate. 
Of the radioactivity in the solubilized sample of strain $\mathrm{Y}$ antigen, $16 \%$ was precipitated by antiserum to strain Y, $12 \%$ by antiserum to PG1 and $13 \%$ by antiserum to PG3. Of the radioactivity in the solubilized sample of PG1 antigen, $13 \%$ was precipitated by antiserum to strain Y or PG1. Some multiple-spotting due to induced charge heterogeneity is present in the gels of precipitated proteins, but this is not a problem and could be reduced by shortening the period of immunoprecipitation. The procedure for solubilizing the immune complexes would dissociate the antigens from the antibodies so it is not considered possible that the immune complexes themselves are an additional source of multiple-spotting. It would be desirable to analyse by two-dimensional electrophoresis those proteins which are not precipitated, in order to show whether proteins were completely removed from the Triton X-100 extract by immunoprecipitation. However, an excessive amount of protein, which necessarily includes the large amount of serum protein, needs to be applied to the gel in order to ensure sufficient radioactivity for detection of the labelled proteins by fluorography. In $M$. gallisepticum, as with $M$. mycoides, only a few proteins were immunoprecipitated, and the major protein antigens were shown to be completely removed from the solubilized extract.

Proteins of strain Y precipitated by antiserum to PG3 gave a gel pattern similar to the central region of Figs. 2 and 3, with major spots at the coordinates $58 \times 50,52 \times 56$ and $33 \times 70$ (results not shown).

\section{DISCUSSION}

The major antigenic component of $M$. mycoides subsp. mycoides is a galactan (Buttery, 1970 ) and that of $M$. mycoides subsp. capri is a glucan (Jones et al., 1965). It is well-established that strains of subsp. mycoides that may be quite distinct in many respects, such as growth rate and colony size on agar (Cottew \& Yeats, 1978) or their ability to grow in the $\rho$-form (Rodwell et al., 1973), are related serologically (Hudson et al., 1967). Subspp. mycoides and capri are unrelated serologically as judged by metabolism inhibition tests, but cross-reactions do occur in double-diffusion and growth precipitation tests (Al-Aubaidi et al., 1972; Ernø \& Jurmanová, 1973). As the polysaccharide components of $M$. mycoides are such strong antigens, the antigenic nature of the cell proteins has received little attention, although Hudson et al. (1967) did report a heat-labile antigen in strain Y which points to the presence of a protein antigen of some importance. Proteins are known to be the major cell antigens in many other mycoplasmas (Kahane \& Razin, 1969; Razin et al., 1972). The work described in this paper shows that strain Y and PG1 are related serologically by their antigenic proteins and that PG3 has protein antigens in common with strain Y. Certainly, PG3 is closer to strain Y than PG1 in its growth characteristics and propensity for growth in the $\rho$-form (Rodwell et al., 1973).

Only a few of the cell proteins gave rise to antibodies after injection of thiomersalatekilled cells into rabbits. It is not known what determines the antigenicity of individual proteins, whether it be a specific hapten or configuration, or simply availability for interaction in the immune system. Antigenic differences among mycoplasma proteins have been observed between different fractions of solubilized Acholeplasma laidlawii proteins separated by gel filtration (Ne'eman et al., 1972) and by crossed immunoelectrophoresis of solubilized mycoplasma proteins (Thirkill \& Kenny, 1974; Johansson \& Hjertén, 1974). Protein A, a major membrane-associated protein of LC strains of subsp. mycoides (Rodwell et al., 1975) was shown to be antigenically important but antibody was not formed against protein $\mathbf{B}$, which is the only protein of the $\rho$-fibre (Rodwell et al., 1975).

The phylogenetic relationships between strains of subspp. mycoides and capri have been studied by two-dimensional gel electrophoresis of cell proteins (Rodwell \& Rodwell, 1978). With this method, proteins with regions of conserved sequence but containing one or more polar mutations would be classed as unrelated whereas immunoprecipitation of solubilized proteins recognizes conserved sequences if these are antigenic. DNA hydridization studies 
have been used in taxonomic studies of $M$. mycoides strains (Askaa et al., 1978). Regions of homologous DNA sequences are recognized by this technique so it is not unexpected that Askaa et al. (1978) found a much higher relatedness between PG1 and PG3 than did Rodwell \& Rodwell (1978) by comparing the cell proteins. Neither method of gaining insight into the genotype gives a wholly accurate representation of the phenotype and a combination of a number of different procedures must continue to be used in taxonomic studies. Immunoprecipitation of mycoplasma proteins may be a useful addition to the range of tests.

This work was carried out during the tenure of a Florey Fellowship. The author is grateful to G. Cottew for the antisera, to S. Buttery for his help with dark-ground illumination and to Dr A. W. Rodwell for encouragement and discussion.

\section{REFERENCES}

Al-Aubaidi, J. M., Dardiri, A. H. \& Fabricant, J. (1972). Biochemical characterization and antigenic relationship of Mycoplasma mycoides subsp. mycoides Freundt and Mycoplasma mycoides subsp. capri (Edward) Freundt. International Journal of Systematic Bacteriology 22, 155-164.

Archer, D. B., Rodwell, A. W. \& Rodwell, E. S. (1978). The nature and location of Acholeplasma laidlawii membrane proteins investigated by twodimensional gel electrophoresis. Biochimica et biophysica acta 513, 268-283.

AskaA, G., Ernø, H. \& OJo, M. O. (1978). Bovine mycoplasmas: classification of groups related to Mycoplasma mycoides. Acta veterinaria scandinavica 19, 166-178.

ButTery, S. H. (1970). Hapten inhibition of the reaction between Mycoplasma mycoides polysaccharide and bovine antisera. Immunochemistry 7, 305-310.

Buttery, S. H. \& Plackett, P. (1960). A specific polysaccharide from Mycoplasma mycoides. Journal of General Microbiology 23, 357-368.

Cottew, G. S. \& Yeats, F. R. (1978). Subdivision of Mycoplasma mycoides subsp. mycoides from cattle and goats into two types. Australian Veterinary Journal 54, 293-296.

ERnø, H. \& Jurmanová, K. (1973). Bovine mycoplasmas: serological studies by double immunodiffusion, growth precipitation and growth inhibition. Acta veterinaria scandinavica 14, 524-537.

Ghangas, G. S. \& Milman, G. (1977). Hypoxanthine phosphoribosyltransferase: two-dimensional gels from normal and Lesch-Nyhan hemolyzates. Science 196, 1119-1120.

HerdersChê, D. (1963). An improved medium for the cultivation of the Eaton agent. Antonie van Leeuwenhoek 29, 154-156.

Hudson, J. R., Cottew, G. S. \& Adler, H. E. (1967). Diseases of goats caused by mycoplasma: a review of the subject with some new findings. Annals of the New York Academy of Sciences 143, 287-297.

JoHANSSON, K.-E. \& HJERTÉN, S. (1974). Localization of the Tween 20-soluble membrane proteins of Acholeplasma laidlawii by crossed immunoelectrophoresis. Journal of Molecular Biology 86, 341-348.

Jones, P. P. (1977). Analysis of H-2 and Ia molecules by two-dimensional gel electrophoresis. Journal of Experimental Medicine 146, 1261-1279.

Jones, A. S., TitTensor, J. R. \& WALker, R. T.
(1965). The chemical composition of the nucleic acids and other macromolecular constituents of Mycoplasma mycoides var. capri. Journal of General Microbiology 40, 405-411.

KaHANE, I. \& RAzIN, S. (1969). Immunological analysis of mycoplasma membranes. Journal of Bacteriology 100, 187-194.

LASKEY, R. A. \& Mills, A. D. (1975). Quantitative film detection of ${ }^{3} \mathrm{H}$ and ${ }^{14} \mathrm{C}$ in polyacrylamide gels by fluorography. European Journal of Biochemistry 56, 335-341.

LAws, L. (1956). A pleuropneumonia-like organism causing peritonitis in goats. Australian Veterinary Journal 32, 326-329.

Ne'eman, Z., Kahane, I., Kovartovsky, J. \& RAzIN, S. (1972). Characterization of the mycoplasma membrane proteins. III. Gel filtration and immunological characterization of Acholeplasma laidlawii membrane proteins. Biochimica et biophysica acta 266, 255-268.

RAZIN, S. (1968). Mycoplasma taxonomy studied by electrophoresis of cell proteins. Journal of Bacteriology 96, 687-694.

Razin, S., Kahane, I. \& Kovartovsky, J. (1972). Immunochemistry of mycoplasma membranes. In Pathogenic Mycoplasmas, pp. 93-122. A Ciba Foundation Symposium. Amsterdam: Associated Scientific Publishers.

Rodwell, A. W. \& Rodwell, E. S. (1978). Phylogenetic relationships between strains of $M y c o-$ plasma mycoides subspp. mycoides and capri studied by two-dimensional gel electrophoresis of cell proteins. Journal of General Microbiology 109, 259-263.

Rodwell, A. W., Peterson, J. E. \& Rodwell, E. S. (1972). Macromolecular synthesis and growth of mycoplasmas. In Pathogenic Mycoplasmas, pp. 123-144. A Ciba Foundation Symposium. Amsterdam: Associated Scientific Publishers.

Rodwell, A. W., Peterson, J. E. \& Rodwell, E. S. (1973). Nature of striated structures in mycoplasmas. Annals of the New York Academy of Sciences 225, 190-200.

Rodwell, A. W. Peterson, J. E. \& Rodwell, E. S. (1975). Striated fibers of the rho form of $M y c o-$ plasma: in vitro reassembly, composition and structure. Journal of Bacteriology 122, 1216-1229.

ThirkiLl, C. E. \& KenNy, G. E. (1974). Serological comparison of five arginine-utilizing Mycoplasma species by two-dimensional immunoelectrophoresis. Infection and Immunity 10, 624-632. 